\title{
The Use of Discretion in German Law
}

\author{
Ernst K. Pakuscher †
}

In the Federal Republic of Germany the exercise of administrative discretion is more narrowly confined than in the United States. The German attitude toward the use of discretion reflects concern about the proper division of legislative and executive functions, the protection of individual rights, and the maintenance of a state based on the rule of law. On the other hand, because of the complex problems of the German welfare state, it is recognized that administrators should be given a degree of discretion in weighing special circumstances in individual cases. Judge Pakuscher outlines the manner in which these conflicting attitudes about the use of discretion have been reconciled doctrinally. and have been accommodated through a system of specialized administrative courts exercising limited review of executive decisions.

In Professor Davis's excellent book Discretionary Justice: $A$ Preliminary Inquiry, ${ }^{1}$ he observes that William Pitt's remark, "Where law ends tyranny begins," might today appropriately read, "Where law ends, discretion begins." Professor Davis eloquently describes the potential for injustice that is posed by the uncontrolled exercise of discretion by government authorities; but he also finds a positive aspect to the use of discretion. "Discretion is a tool, indispensable for individualization of justice. . . . Rules alone, untempered by discretion, cannot cope with the complexities of modern government and of modern justice. Discretion is our principal source of creativeness in government and in law." Because of this promising side to the use of discretion, Professor Davis sets forth the following goal for the legal system: "Where law ends individualized justice begins." Bearing this goal in mind, I prepared the following article on the role and the control of discretion in the law of the Federal Republic of Germany.

$\dagger$ Chief Judge of the Federal Patent Court of the Federal Republic of Germany, former Judge of the Federal Supreme Court for Administrative Cases, Dr. iur. (Munich 1952), LL.M. (Berkeley 1956).

1 K. Davis, Discretionary Justice: A Preliminary Inquiry (1969).

2 Id. at 3.

${ }^{3}$ Id. at 25 .

Id. at 21. 


\section{The Constitutional Issues}

After the National Socialist regime and the four-year postwar interregnum, the legal framework of the Federal Republic of Germany was established with the proclamation of the Basic Law on May 23, 1949. The constitutional scheme of the Federal Republic of Germany is designed to protect individual rights against governmental power, but it also imposes on the government the complex responsibilities of a modern social welfare state. These two competing emphases within the constitutional framework are spoken of as the principle of the Rechtsstaat-the state based upon the rule of law-and the principle of the Sozialstaat.

Although the Constitution does not specifically address the subject of discretion, the exercise of discretion by public authorities necessarily raises constitutional questions about the relationships among the three branches of government ${ }^{5}$ and between the rights of the individual and the power of the state. ${ }^{6}$ For authoritative answers to these questions, one must look to the opinions of the Federal Constitutional Court (Bundesverfassungsgericht) at Karlsruhe.?

\section{A. The Legislature and the Executive-the Grant of Discretion}

The usual, though not the only, sphere of discretionary power in the Federal Republic of Germany is the exercise of discretion by an officer of the executive branch acting pursuant to statutory authorization. In this context the authority, indeed the duty, to make a discretionary decision is conferred on the administrator so that a legislative program can be more effectively and justly imple-

s The Basic Law, or Constitution, of the Federal Republic of Germany establishes the principle of separation of powers betwen the legislative, executive, and judicial organs. GRUNDGESETZ [GG] art. 20, para. 2.

- GG ch. I (Basic Rights).

7 This Court is unique both in its structure and in its role within the judiciary of the Federal Republic of Germany. The Federal Constitutional Court was created by Federal Act of March 12, 1951, [1951] Bundesgesetzblatt [BGB1] I 243. The justices of the Court's two Senates (Divisions) are elected by special bodies of the Parliament and appointed by the President of the Federal Republic of Germany, generally for twelve-year terms without any possibility of being reappointed. The main task of the Federal Constitutional Court is taken from the tradition of the United States Supreme Court-it has the power to rule on the constitutionality of legislative acts. However, the Federal Constitutional Court is a special court that decides only constitutional questions submitted to it by general courts in the course of pending litigation, or by individual parties who have exhausted their other legal remedies through recourse to civil, criminal or other courts. Thus, the Federal Constitutional Court is not a "Super-Supreme Court," entitled to set aside lower court decision, but merely an independent special tribunal for constitutional questions. Its decisions are binding with the force of law upon the executive, legislature, and judiciary. 
mented. In essence, the administrator is allowed to make the most appropriate choice in each case from among several equally legal alternatives. This grant of discretion may be distinguished from the situation, termed bound administration (gebundene Verwaltung), where the administrator is required to reach the one result that would be legal under each set of circumstances as defined by statute.

The Federal Constitutional Court has declared legislative grants of discretion to be consonant with the rule of law and not in violation of the constitutional relationship between the legislature and the executive. However, it has held unconstitutional laws that delegate discretionary power without furnishing guidelines for its exercise. In one case decided in 1958, a regulation that made the planting of vine shoots subject to an official permit, without indicating the conditions under which the permit was to be granted, was declared unconstitutional. ${ }^{8}$ A similar result was reached in 1966 with respect to a law that made the taking of public collections subject to a special permit, without clarifying the conditions under which the permit was to be given. ${ }^{9}$ In these cases in which the legislature failed to provide standards for deciding whether or not to grant a permit, the unguided power thus conferred upon the administrator was held to violate the Constitution. ${ }^{10}$

A different result was reached in a case challenging the constitutionality of a federal law that imposed a fine for the nonuse of import licenses. ${ }^{11}$ The statute permitted but did not require an administrative officer to restrain from exacting the fine if the licensee was not at fault for the nonuse, ${ }^{12}$ thus leaving the decision in such cases to the administrator's discretion. The Court upheld the constitutionality of this grant of discretion, noting that although the Constitution requires that a statute clearly set forth the circumstances in which an administrator may interfere with an individual's legally protected rights, it does not require the legislature to bind an administrator to interfere in every case, or to prescribe the exact circumstances in which an administrator may refrain from interfer-

8 Judgment of July 10, 1958, 8 BVerfGE 71.

- Judgment of Aug. 5, 1966, 20 BVerfGE 150.

10 See GG art. 80 (requiring that any statute authorizing the federal government, a federal minister, or the state governments to issue ordinances having the force of law must set forth the content, purpose, and scope of the authorization).

" Judgment of Feb. 3, 1959, 9 BVerfGE 137. During the early 1950s the federal government was actively engaged in the regulation of imports to control the balance of payments deficit. Licenses were issued in limited numbers to importers; to prevent abuses of the system a fine was authorized for nonuse of a license.

${ }^{12}$ Law of Dec. 27, 1951, [1951] BGBl I 1005. 
ence. The limited discretion involved in the decision not to interfere is constitutional, if exercised in accordance with the purpose of the statute.

\section{B. The Executive and the Judiciary-the Review of Discretion}

Judicial review of administrative actions is recognized in Article 95 of the Basic Law which establishes a separate Federal Supreme Court, whose jurisdiction extends in principle to any administrative act. Administrative law courts ${ }^{13}$ are not permitted to review the expediency of discretionary decisions, but can, and do, review their legality-whether the law was correctly applied, whether the administrative authority stayed within the limits of its discretion, and whether the decision was free from extraneous considerations. As the Federal Constitutional Court has stressed, the availability of review by independent courts helps make discretionary powers within the executive branch constitutionally tolerable. ${ }^{14}$ In upholding the constitutionality of the statute in the import license case mentioned above, the Court emphasized that when disputes arose about an administrative officer's decision not to waive the fine, a full judicial review of the administrative decision would be available to determine whether the administrator had disregarded the purposes of the law, or the constitutional right of equal treatment.

\section{Individual Rights and Discretionary Power}

The most fundamental constitutional issues raised by the use of discretion pertain to constitutionally protected rights. A case illustrating this point involved a challenge to a provision of the Federal Law on Passport Matters ${ }^{15}$ setting forth the conditions for the denial of a passport by the administrative authorities. Because the freedom to travel outside the Federal Republic of Germany is considered to be a basic component of the general rights of liberty secured by Article 2 of the Constitution, ${ }^{18}$ the issuance of a passport

13 The top administrative law court is the Federal Administrative Court (Bundesverwaltungsgericht) in Berlin. Administrative trial courts and courts of appeals are state (Land) courts.

is Judgment of June 16, 1959, 9 BVerfGE 338, 353.

is Law of Mar. 4, 1952, [1952] BGBl I 290.

16 (1) Everyone shall have the right to the free development of his personality in so far as he does not violate the rights of others or offend against the constitutional order or the moral code.

(2) Everyone shall have the right to life and to inviolability of his person. The liberty of the individual shall be inviolable. These rights may only be encroached upon pursuant to a law.

GG art. 2. 
may be compelled by court action. Section 7 of the challenged statute provides that a passport shall not be issued if granting a passport to the applicant would endanger the internal or external security "or other essential interests" of the Federal Republic of Germany. The Constitutional Court emphasized that the imprecise phrase "other essential interests" carried with it the danger that the denial of passports would be left to the unreviewable discretion of administrative officers. ${ }^{17}$ If that were so, the provision would be unconstitutional, for the legislature may not delegate to the executive the authority to define the boundaries of individual liberties "by means of an indeterminate general clause."18 However, the court was able to avoid this result by interpreting the ambiguous phrase not as a grant of discretion, but as an "indefinite legal concept," 19 which meant that its application was fully reviewable by the administrative law courts.

In sum, administrative discretion is clearly established within the constitutional order of the Federal Republic of Germany, but its position is highly sensitive to the balance between the state and the individual and to the allocation of roles among the legislative, executive, and judicial branches in maintaining that balance. With this perspective we may now turn to a brief survey of discretion within several areas of German law and problems presented in particular cases.

\section{A Survey of the Use of Discretion in German LaW}

\section{A. The Scope of Discretion}

In the Federal Republic of Germany the degree of discretion that may be delegated to government authorities varies widely, depending on such factors as the nature of the discretionary choice and whether basic individual rights are at stake. The German system of initiation of prosecution for serious criminal offenses, which has received considerable attention in America, ${ }^{20}$ is one area where little or no discretion is allowed.

Contrary to the American practice, in the Federal Republic of

17 Judgment of Jan. 16, 1957, 6 BVerfGE 32.

is Id. at 42.

19 When a statutory term is determined to be an indefinite legal concept, e.g., "the needs of the public," "necessity," "reliability," "fitness for a purpose," its interpretation is regarded as a question of law and therefore subject to complete review by the courts.

${ }^{20}$ See, e.g., Herrmann, The Rule of Compulsory Prosecution and the Scope of Prosecutorial Discretion in Germany, 41 U. CHI. L. REv. 468 (1974); Langbein, Controlling Prosecutorial Discretion in Germany, 41 U. CHI. L. REv. 439 (1974). 
Germany the decision of a prosecutor to file a bill of indictment, and the decision of a judge to fix a date for trial based on the preliminary findings of the prosecutor, involve very little discretion. Under section 152(2) of the Code of Criminal Procedure, the prosecutor is obliged to act on information concerning any punishable criminal act. Accordingly, if a prosecutor is informed of a possible crime, he must immediately initiate an investigation, ${ }^{21}$ and if his investigation reveals sufficient cause, he must file a bill of indictment. ${ }^{22}$ Similarly, if there is sufficient evidence that the accused has committed a punishable act, the court must hold a plenary trial. ${ }^{23}$ The decisions of the prosecutor and the judge are not, strictly speaking, discretionary rulings, but represent the application of specific statutory provisions and are subject to full judicial review by appellate courts. ${ }^{24}$ Accordingly, under German law, a prosecutor or a judge may be liable for damages for having negligently instituted a criminal proceeding ${ }^{25}$ - a possibility that would not be present if the prosecutor or judge had any discretion in the matter.

At the opposite extreme are cases where an administrator has nearly full discretion in making a particular decision. An illustration of broad discretion is the so-called administrative political discretion doctrine. ${ }^{26}$ Administrative political discretion is involved, for example, in a decision of the executive to build a new street or to establish a new town. Such decisions are generally exempt from judicial control. ${ }^{27}$ This policy of noninterference follows from the general principle of the separation of powers ${ }^{28}$ and from the inevitability that the interpretation of terms like "public interests" (offentliche Belange) in such cases will involve discretion. For example, the conception underlying the plan of a new community will determine what corresponds to or violates "public interests" in executing that plan. Despite the demand for a full judicial review of discretionary decisions, administrative spheres such as these continue to be exempt from judicial control. These spheres of discretion ought to be respected.

21 STRAFPROZESSORDNUNG [STPO] $\S 160(1)$.

22 STPO § 170(1).

$23 \mathrm{STPO} \S 203$.

24 E.g., STPO \& 172 (where the victim presses charges); STPO $\$ 210$ (2) (other cases).

25 Judgment of June 18, 1970, BGH (Nürnberg), in 23 NeUE JURISTISCHE WochENSCHRIFT [NJW] 1543 (1970).

26 Kellner, Einiges zum behördlichen Ermessen, 1969 Die ÖfFEnTliche Verwaltung [DÖV] 309, 311.

27 H. Rupp, Grundfragen der heUtigen Verwaltungslemre 209 (1965).

2x GG art. 20(2). 
Between these extremes, the scope of discretion granted to the executive branch varies widely, depending on the terms of the statute, the requirements of the Constitution, and the principle of the rule of law. A 1971 decision of the Federal Supreme Court concerning the system in use in the Federal Republic of Germany for protecting children from pornographic materials exemplifies the sensitivity of the judiciary to the different factors affecting the scope of discretion. ${ }^{29}$ By Federal Act of June 9, 1953 a special federal agency (Bundesprüfstelle) was established for the registration of literature, records, and films apt to endanger the morals of children or juveniles. ${ }^{30}$ The registration must be published in an index, and after publication the item concerned may not be sold, let, or otherwise made accessible to children or juveniles. The Federal Supreme Court ruled that the agency is authorized to use its discretion in evaluating whether or not an item should be placed on the register. The statute requires that to be registrable a work must be "apt to endanger juveniles.' 31 This prerequisite had previously been considered nondiscretionary, that is, allowing only one correct decision on each set of facts. However, before a certain work may be banned not only do facts have to be ascertained and measured against pertinent statutory provisions, but an evaluative decision is called for. The assumption that the term "apt to endanger juveniles" allows only one correct decision therefore must be considered false. Due to the nature of the subject matter, the potential range of legally valid decisions is broad. ${ }^{32}$

Furthermore, the decision-making agency embodies an important element of social representation. The agency operates through a panel of twelve members, including its President, three officials appointed from various states (Länder) of the Federal Republic of Germany, and eight members chosen from among the authors of literary or artistic works, publishers, booksellers, youth organizations, youth welfare institutions, teachers' associations, and churches. In order to register a work as endangering juveniles, a twothirds majority of those taking part in the decision is required with at least seven members of the panel voting with the majority. Thus, the composition of the board combines professional knowledge with elements of representation, allowing various social groups to exer-

29 Judgment of Dec. 16, 1971, 39 BVerwGE 197.

${ }^{30}$ [1953] BGBl I 377, amended by [1961] BGBl I 497.

31 Id.

${ }^{32}$ Redeker, Fragen der Kontrolldichte verwaltungsgerichtlicher Rechtsprechung, 1971 Döv 757, 762. 
cise their influence in individual cases. Under these circumstances, the Federal Supreme Court deemed it improper for an administrative law court, aided by court-appointed experts, to set aside the decision of the panel..$^{33}$

This does not mean that decisions of the board are exempt from judicial review. On the contrary, administrative law courts may determine whether the board has ascertained the pertinent facts correctly and completely, whether it has observed the appropriate standards in these matters, and whether it has given sufficient reasons for its decision. Otherwise, the decision of the board will be set aside. ${ }^{34}$

\section{B. Judicial Review of Discretionary Decisions.}

Under section 114 of the Rules of Procedure for Administrative Law Courts, ${ }^{35}$ the courts must fully review decisions of administrators for errors of law and for mistakes in ascertaining the necessary facts, but may not review the wisdom of administrative decisions. Two cases involving the regulation of civil service employees illustrate the manner in which administrative law courts apply this scope of review to different types of discretionary action by government authorities.

The first case involved the denial of a special permit required for a member of the civil service to take on a paid part-time job. According to the statutory rules, the civil service employer has discretion to grant the permit. Examples given by the statutes indicate that the permit must be denied if the part-time activities would either be incompatible with the status of the official or would take so much of his time or working capacity that the full performance of his official duties would be jeopardized. The local court for administrative law cases at Düsseldorf has ruled that the discretion to grant or deny a permit is limited by the official interest of the governmental authority involved. ${ }^{36}$ Thus, if the official position of the civil servant provides no grounds to restrict his freedom to look

33 Judgment of Dec. 16, 1971, 39 BVerwGE 197, 204.

34 This judgment of the Federal Supreme Court has met with general approval, but also with some mild and sharp criticism. See Ott, Die neue Rechtsprechung des Bundesverwaltungsgerichts zum literarischen Jugendschutz in verfassungsrechtlicher Sicht, 25 NJW 1219 (1972); Müller, Annot., 25 NJW 1587 (1972); Schmidt-Salzer, Annot., 87 Deutsche VerwaltungsBlatT [DVBl] 391 (1972); Ule, Unbestimmte Begriffe und Ermessen im Umweltschutzrecht, 88 DVBl 756, 762 (1973).

3s VerwaltungsGerichtsordNuNG [VWGO] § 114.

34 Judgment of Sept. 19, 1973, VG Düsseldorf, in 53 Deutsche Richterzeitung [DRiZ] 24 (1975). 
for part-time work, a permit must be granted. To effectuate review, the court required that when denying a permit the civil service employer must disclose all the factual circumstances and the reasoning that formed the basis of the decision. Only by a full disclosure will the courts be able to ascertain whether or not a case involves an abuse of discretion. In the reported case the contested denial was set aside and the agency was instructed to consider and decide the matter de novo pursuant to the ruling of the court. ${ }^{37}$

The second decision involved the vice principal of an elementary school, who had been transferred to another school over her objection. ${ }^{38}$ The transfer was due to long-standing tensions between the vice principal and her superior, the principal of her old school. She filed an action to prevent her transfer, and the local administrative law court dismissed her suit. Her first appeal was unsuccessful, but on an appeal to the Federal Supreme Court the case was remanded for a new trial. Under the pertinent statute a civil servant may be transferred to another post upon his request or for official needs. ${ }^{39}$ The transfer in this case was purportedly for official needs. While the Federal Supreme Court demanded a judicial review of the finding of an "official need" (dienstliches Bedürfnis), it stepped back from interfering with the placement of individual members of the civil service. The court ruled that whether the plaintiff or her superior had to be transferred was a decision resting within the power of those responsible for planning and administering the school system. Nevertheless, the case was remanded to the lower court, which had erroneously deemed itself bound to accept the decision of the school authority without examining whether the principle of proportionality (Prinzip der Verhältnismässigkeit) had been observed-for example, whether there had been an effort to reconcile the plaintiff with her colleagues or supervisors so that a transfer could be avoided.

Thus, despite the desire and need for full judicial review, the courts are careful not to interfere with the daily work of the executive branch if at all possible. In the second case this attitude meant that, although the court did not refrain from reviewing the contested

${ }^{37}$ Cf. 23 NJW 2313, 2314 (1970) (reporting another decision of the Federal Administrative Court concerned with the borderlines of discretion in proceedings over permits for parttime professional activity).

3s Judgment of Jan. 25, 1967, 26 BVerwGE 65, confirmed in Judgment of Mar. 19, 1969, 31 BVerwGE 345, 358.

3* Beamtengesetz [Law on the status of civil servants] für das Land NordrheinWestfalen [LBG], as published June 1, 1962, § 28, [1962] Gesetz- und Verordnungsblatt für das Land Nordrhrein-Westfalen [GV NW] 271. 
decision, it accepted a significant and perhaps decisive factor as resting within the special expertise of the authority involved..$^{40}$

While the Federal Constitutional Court has placed considerable emphasis on the availability of judicial review of discretionary action, there is some empirical evidence that judicial review plays only a small role in controlling the executive. One of Professor Davis's pupils and admirers, Stephan Von Welck, conducted an investigation of thirty-eight state authorities in charge of requests of citizens for changes of their names. ${ }^{41}$ Under the relevant law, ${ }^{42}$ the administrative authority can grant a requested change in family name only if the change is justified by an "important reason." The meaning of the term "important reason" has been spelled out by special directives of the Federal Government that are binding on the authorities involved. ${ }^{43}$ If the authority comes to the conclusion that an important reason exists, it must then decide whether the change of name is suitable. This second step involves the exercise of discretion or evaluation.

Von Welck submitted questionnaires to the thirty-eight authorities, receiving a response from slightly over half. He found that between 1966 and 1970 the responding authorities considered 4,724 requests for name changes; of these 3,776 were granted, 261 were denied, 413 were withdrawn, and 274 remained pending. Furthermore, the administrative law courts were only rarely asked to intervene after the denial of an application for a change of name: out of the 261 refusals only 45 were challenged by court action-representing only $17 \%$ of all the requests turned down by the administration and only $1 \%$ of all reported administrative proceedings. Only in these few cases was judicial control of administrative discretion exercised, in spite of the legal possibility of judicial review in every case.

Although it should not be overlooked that the field of activities chosen by Von Welck is not typical of the manifold and frequently much more contentious decisions of the executive branch, it can be said in general that judicial control is not as comprehensive as is usually assumed. His figures indicate that the theoretical possibility of the review of administrative decisions by independent courts must not be equated with the control exercised by administrative law courts in reality.

to See Kellner, Einiges zum behordlichen Ermessen, 1969 DÖV 309, 312.

"Von Welck, Rechtstatsachenuntersuchungen zum Verwaltungsermessen, 1973 DÖV 732.

12 Law of Jan. 5, 1938, [1938] Reichsgesetzblatt [RGBl] I 9.

[1 [1961] Gemeinsames Ministerialblatt 13. 
The study suggests that the prevailing opinion that discretionary injustice can be eliminated by a maximum of judicial review ${ }^{44}$ should be reexamined. At the very least, reliance on judicial review to control discretion should be supplemented by efforts to strengthen administrative procedure by developing generally acceptable standards that will enable administrators to resolve cases of conflicting interests according to principles of equal justice. This goal has been partly achieved by a very recent Federal Act of May 25,1976 regulating the administrative procedure of federal agencies and state agencies applying federal laws. ${ }^{45}$ One provision of the Act requires an authority exercising discretion to state the facts and reasons for its decisions; ${ }^{46}$ another provides that an authority empowered to use discretion must exercise it in accordance with the purpose of the authorization, and keep within the limits of discretion set by the statute. ${ }^{47}$

At the same time the administration should overcome its suspicion of judicial control. After World War II, at the beginning of our young democracy, administrative authorities had to work under the most dreadful circumstances. Administration was especially difficult in the fields of housing, where there was a tremendous shortage of rooms and apartments, and food rationing. In both areas thousands of executive decisions were made daily. The administration was afraid that the creation and reopening of administrative law courts and the introduction of their comprehensive jurisdiction would seriously hamper its daily work. It was surprised to discover, however, that in the large majority of cases the courts upheld administrative decisions. This was due not to any special judicial friendliness towards the administration, but to the soundness of the executive decisions. Because the executive is bound by law and justice under the Constitution ${ }^{48}$ the scope of judicial review mandated by section 114 of the Rules of Procedure for Administrative Law Courts provides an adequate "check point" to set aside faults and mistakes in the exercise of discretion by administrative agencies, without unduly interfering with the freedom of the executive branch to act.

" See, e.g., K. Davis, Discretionary Justice: A Preliminary Inquiry (1969); H. Ehmke,

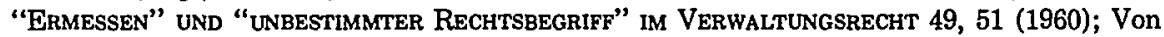
Welck, supra note 41.

is Verwaltungsverfahrensgesetz [VwVfG], [1976] BGBl I 1253.

st Id. $\$ 39(1)$ sent. 3.

${ }^{17}$ Id. $\$ 40$.

s8 GG art. 20(3). 


\section{Discretion and Individual Rights}

One of the more interesting recent decisions of the Federal Supreme Court concerning the possible intrusion of administrative discretion on constitutionally protected individual rights involved the following facts. ${ }^{49}$ The regional management of the state-owned German railroad at Karlsruhe from time to time invites up to twenty news reporters to participate in press excursions by train. The plaintiff, a news reporter who was entitled to attend press conferences of the railroad, had not received invitations to attend any of these instruction tours. He sued, asking that the railroad be ordered to invite him to such excursions in the future, but the action failed at all levels of the administrative courts. The Federal Supreme Court ruled that the plaintiff had no enforceable "right" to go on these excursions. The Court found the limitation on the number of participants in such excursions to be a matter of discretion, qualified, however, by the constitutional principle of equal treatment. ${ }^{50}$ Accordingly, the railroad could not select reporters from "good" and "bad" newspapers, or invite only those who had in the past reported favorably on the performance of the railroad or of other public institutions. Similarly, the Court ruled that the principle of freedom of the press was not at stake, provided the selection of participants did not result in the regimentation of all or a part of the press. In the present case there was no indication of such regimentation since the plaintiff had not submitted any evidence showing that his professional work was predominantly devoted to transportation problems. Thus, his exclusion from the excursions did not violate the provision of the Constitution guaranteeing a free press. ${ }^{51}$

\section{Conclusion}

More than 20 years ago, Professor Hans Huber observed that the use of discretion-" "the Trojan Horse of classical administrative law"52_had not yet been fully reconciled with the ideal of the rule of law. This remains as true today as it was then.

\footnotetext{
3udgment of Dec. 3, 1974, 47 BVerwGE 247.

so GG art. 3.

st GG art. 5.

52 Obermayer, Die Beurteilungsfreiheit der Verwaltung, 1975 BAYERISCHES VeRwaltungs-
} BLÄTTER 258. 


\section{A. The Doctrinal Problem}

The reason discretion rests uneasily within the German system of law is that it necessitates a compromise between two fundamental and conflicting goals of the legal order. On the one hand, protecting citizens from arbitrary applications of the executive power of the state requires that citizens receive equal treatment under fixed and ascertainable rules of law. On the other hand, the fullest realization of justice in individual cases and the practical needs of the executive often require that the decision maker have a measure of freedom to recognize and weigh special circumstances and factors the legislature could not have anticipated or subsumed under a comprehensive formula. Some instances of the need for administrative discretion involve only expediency, such as the problems of the design and the location of facilities in city planning. More often, administrative discretion relates to problems of individualized justice: balancing interests, minimizing governmental interference with individuals, and ensuring uniformity of treatment.

The threshold question in the development of a legal doctrine of discretion is whether the use of discretion is per se unconstitutional. In ruling that it is not, ${ }^{53}$ the Federal Constitutional Court closed the door to the appealingly simple "radical approach" to the problem of controlling discretion and set upon the difficult task of developing legal principles to guide the exercise of discretion.

German legal doctrine in this area begins with the recognition that the purposes served by administrative discretion do not require an absolute freedom of decision, but can be fulfilled by a closely restricted power to choose among several equally legal alternatives. The degree of discretionary freedom granted to an administrator varies considerably, but always within limits, and involves the facts that he may consider, the manner in which his decision may be reached, and the alternative solutions he may reach. The pertinent statute may prescribe which values are to be considered and in which sequence. However, even if the statute purports to grant "free discretion" (freies Ermessen), the administrator is bound to decide issues consistently with the purpose of the statute ${ }^{54}$ and in accordance with general legal principles, whether they derive from the Constitution or from the basic principle of the rule of law.

The present state of German legal doctrine regarding standards for the exercise of discretion contains a curious anomaly. Although

33 See, e.g., Judgment of Feb. 3, 1959, 9 BVerfGE 137.

s VwVfG \& 40, supra note 45 . 
the relevant principles limiting the use of discretion-for example, the principle requiring equal treatment-should be equally binding no matter which source they derive from, in actuality the scope of judicial review may depend on whether the pertinent principle is recited in the relevant statute or is derived from the Constitution. If the principle has been enacted in a specific statutory provision, compliance with the standard is fully reviewable by the courts; if the standard is derived from the Constitution, however, the administrative authority is granted a broader sphere of discretion. ${ }^{55}$ Of course, when the relevant principle is derived from the Constitution or the concept of the rule of law, the administrative authority may not pursue its goals ad libitum, but must apply objective criteria, balancing in a just and reasonable manner the various interests affected. Thus, even in cases governed by constitutional principles the exercise of discretion is not free, but is bound by the duty of the administrators to act under the guidance of principles of law and justice (pflichtmässiges Ermessen).

\section{B. Institutional Controls on the Exercise of Discretion}

The doctrinal reconciliation of the need for administrative discretionary powers and the ideal of the rule of law finds its parallel in the arrangement of institutional safeguards against the abuse of discretion. To protect citizens from errors in the exercise of administrative discretion, the German system has placed primary emphasis on the review of administrative decisions ${ }^{56}$ by special administrative law courts having full independence from the executive. This structure is designed to accommodate the conflicting goals of the administration, which is responsible for carrying out legislative programs, and of the judiciary, which is responsible for protecting individuals from unlawful acts of the administration.

These competing interests and functions have sparked a continuing quest for reforms that will bring about an optimal balance. One proposed reform would structure complex administrative proceedings as a series of distinct administrative acts, each subject to review by the administrative courts. If the decision at each stage is not contested at the time it is made, it is not subject to judicial review at a subsequent step in the administrative process. This is the practice, for example, in the assessment of property taxes, where the valuation of real estate precedes the separate decree of the tax

ss Judgment of Apr. 26, 1968, 29 BVerwGE 304, 307.

st Laubinger, Staatrechtslehrertagung 1975 (pt. 2), 91 DVBl 289, 290 (1976). 
assessment. However, the theory of successive administrative acts seems unsatisfactory as a general solution to the problem of facilitating judicial review due to the delay and added costs it would impose on the administrative system.

A critical point of potential conflict between administrators and courts concerns the scope of the reviewing court's inquiry and its power to impose an alternative outcome. It has to be remembered that the exercise of discretion involves the realization of administrative goals as well as the application of law to particular facts. The power of judicial review is said to extend only to the latter aspect of the administrator's act. This balance between executive and judicial powers has been defined in section 114 of the Rules of Procedure for Administrative Law Courts.

The role of an independent judiciary exercising a limited power to review administrative actions has been challenged by a proposal to create within the executive branch special boards empowered to review administrative acts as to both their legality and their expediency. ${ }^{57}$ Administrative law courts would continue to be restricted to a review of the legality of decisions involving the use of discretion. The argument advanced in support of this proposal is that the courts are too insensitive to the policies and objectives of the administration, but it is difficult to see how administrative review boards would, in fact, be any more sensitive. At best, an additional organ for review within the executive branch might be able to ascertain and correct deficiencies in administrative practice- a function better suited to an ombudsman than to formal review boards. ${ }^{58}$

The most recent development in the German law of administrative discretion was the enactment on May 25, 1976 of the Federal Law on Administrative Procedure.59 Some of the principal provisions of this act pertain to matters already discussed, such as the express provision that discretion must be exercised within the statutory limits and according to the purpose for which it was authorized. ${ }^{60}$ In addition, however, the act requires that discretionary decisions be accompanied in most cases by a statement of reasons disclosing the basis for the decision. ${ }^{61}$ The disclosure of reasons is not

37 Enquete-Kommission für Fragen des Verfassungsreform, ZWischenbericht [Enquete-Comm'n for Constitutional Reform, Intermediate Report], BundestaGsDRUCKSACHE VI/3829 § 3.4.2 (Sept. 21, 1972).

${ }_{5 *}$ Bullinger, Ermessen und Beurteilungsspielraum-Versuche einer Therapie, $27 \mathrm{NJW}$ 769, 772 (1974).

${ }_{59}$ Verwaltungsverfahrensgesetz [VwVfG], [1976] BGBl I 1253.

${ }^{60} I d . \S 40$.

6I Id. § 39 . 
only a fundamental requirement of fairness, but a prerequisite for judicial review, as the administrative courts have long stressed. In addition to these traditional tenets of administrative law, the 1976 Act contains procedural requirements that operate to improve the quality of administrative justice without recourse to judicial review. Among these are the provisions that citizens are authorized to inspect pertinent records, ${ }^{62}$ that applicants normally have a right to a hearing prior to the rendering of a decision that could impair their rights, ${ }^{63}$ and that the authorities are under a duty to advise citizens about their rights in an administrative proceeding. ${ }^{64}$ The statute will become effective on January 1, 1977. That it will have considerable impact is already apparent.

Neither the improvements in administrative procedure-as important as they may be-nor the creation of independent administrative boards with full competency to review matters of both fact and law are sufficient to dispense with the control of administrative discretion by independent courts hearing and deciding administrative law cases. Since such courts do not exist to the same extent in the United States as in the Federal Republic of Germany, Professor Davis's professed desire for more justice in the field of discretionary decision making remains an important and urgent goal in his country. This goal also remains important in Germany, however, where it is still necessary to search for ways to assure expeditious and effective individual legal protection, without unduly constricting the free, creative activity that the administration needs in our century of increasing demands for equal treatment and social justice. ${ }^{65}$

"Id. § 29(1).

cs Id. \& 28(1).

s Id. \& 25.

* Bullinger, supra note 58, at 773 . 